\title{
Copper Stabilization in Beneficial Use of Waterworks Sludge and Copper-laden Electroplating Sludge for Ceramic Materials
}

\author{
Kaimin Shih", Yuanyuan Tang \\ Department of Civil Engineering, The University of Hong Kong, Pokfulam Road, \\ Hong Kong SAR, China
}

\section{INTRODUCTION}

Industrial processes such as electroplating always produce solid sludge containing significant amounts of toxic metal-laden compounds (Peng \& Tian, 2010). In China, electroplating sludge discarded every year contains more than 100,000 tons of hazardous metals (Wang, 2006). A widely accepted treatment process is the stabilization/solidification (S/S) method, which can convert hazardous wastes into chemically stable solids (Sophia \& Swaminathan, 2005; Chen et al., 2011). The S/S method achieves pollutant encapsulation through an interlocking framework of hydrated minerals (Sophia \& Swaminathan, 2005; Zhou et al., 2006). In general, the S/S products are ultimately disposed of in secure landfills (Chen et al., 2011). Even after solidification and encapsulation, the metal-laden sludge still exhibits considerable long term metal leachability (Yousuf et al., 1995). The limited number of landfills capable of accepting S/S substances, together with their adverse environmental impacts (Malviya \& Chaudhary, 2006), has made the development of effective and financially viable treatment technologies essential.

In our previous studies (Tang et al., 2010; 2011), the simulated copper-sludge were found to be able to react with the aluminum-rich precursors and form $\mathrm{CuAl}_{2} \mathrm{O}_{4}$ spinel phases after a 3-h sintering process. The metal leachability after thermal treatment was also significantly reduced due to the formation of spinel phases (Tang et al., 2010; 2011). As a waste-to-resource technology, the use of waste sludge resulting from water and wastewater treatment processes has attracted much attention (Babatunde \& Zhao, 2007). In water treatment, for example, all processing systems generate a substantial amount of sludge with the residues of treatment chemicals used as coagulants (commonly aluminum-based), and the use of aluminum-rich sludge as raw material for ceramic products has shown promise (Vicenzi et al., 2005).

Since water treatment works in Hong Kong use aluminum-based coagulants (aluminum sulphate, aluminum chloride, poly aluminum sulphate, etc.) to facilitate particulate sedimentation. In this study, we attempted to evaluate the potential use of such waterworks sludge for immobilizing metal-laden electroplating sludge within a 3-h sintering scheme. 


\section{MATERIALS AND METHODS}

\subsection{Sample preparation}

The Cu-containing electroplating sludge was collected from an industrial sludge treatment facility in Guangdong Province in China, and the collected sludge was dried at $105{ }^{\circ} \mathrm{C}$ for further sintering experiments in this study. The sludge elemental compositions detected via X-ray fluorescence spectroscopy (XRF; JEOL JSX-3201Z) was normalized by their oxide forms (Table 1) and showing copper as the predominant constituent. A waterworks sludge sample collected in Hong Kong was heated for using as an aluminum-rich ceramic precursor. The sludge was dried and fired at $900{ }^{\circ} \mathrm{C}$ for $30 \mathrm{~min}$ to remove the organic content and then ground into powder for elemental composition analysis by XRF. Normalization into metal oxides (Table 2) shows aluminum to be the predominant constituent. Samples for sintering experiments were prepared by mixing $900{ }^{\circ} \mathrm{C}$ calcined waterworks sludge with the dried electroplating sludge for a total dry weight of $60 \mathrm{~g}$ at a $\mathrm{Cu}: \mathrm{Al}$ molar ratio around 1:2.5 (with excess alumina available for copper incorporation). The mixing process was carried out by ball milling the powder in water slurry for $18 \mathrm{~h}$. The slurry samples were dried and homogenized by mortar grinding, pressed into 20-mm pellets at 480 MPa to ensure consistent compaction of the powder samples for the sintering process.

Table 1-Major compositions of the dehydrated copper-bearing electroplating sludge

\begin{tabular}{lccccccc}
\hline Components & $\mathbf{C u O}$ & $\mathbf{S O}_{3}$ & $\mathbf{A l}_{2} \mathbf{O}_{3}$ & $\mathbf{S i O}_{2}$ & $\mathbf{C a O}$ & $\mathbf{F e}_{2} \mathbf{O}_{3}$ & Others \\
\hline $\begin{array}{l}\text { Weight Percentage } \\
\text { (wt\%) }\end{array}$ & 64.74 & 19.91 & 4.94 & 3.19 & 3.07 & 2.57 & 0.77 \\
\hline
\end{tabular}

Table 2-Major compositions of incinerated waterworks sludge.

\begin{tabular}{lcccccccccc}
\hline Components & $\mathrm{Al}_{2} \mathrm{O}_{3}$ & $\mathrm{SiO}_{2}$ & $\mathbf{P}_{2} \mathrm{O}_{5}$ & $\mathbf{F e}_{2} \mathrm{O}_{3}$ & $\mathbf{S O}_{3}$ & $\mathrm{~K}_{2} \mathbf{O}$ & $\mathbf{C a O}$ & $\mathbf{T i O}_{2}$ & $\mathbf{M n O}$ & $\mathbf{A s}_{2} \mathbf{O}_{3}$ \\
\hline $\begin{array}{l}\text { Weight } \\
\begin{array}{l}\text { Percentage } \\
\text { (wt\%) }\end{array}\end{array}$ & 56.53 & 30.16 & 3.81 & 6.17 & 0.55 & 1.28 & 0.48 & 0.31 & 0.66 & 0.05 \\
\hline
\end{tabular}

\subsection{Metal incorporation}

To identify the potential phases responsible for the metal incorporation mechanisms in a 3-h short sintering scheme, the pelletized powder mixture samples were fired in a high-temperature furnace (LHT 02/16 LB, LBR, Nabertherm Inc.) for a fixed 3-h dwelling time at targeted sintering temperatures ranging from 750 to $1250{ }^{\circ} \mathrm{C}$. After sintering, the samples were air-quenched and ground into powders for XRD analysis and the leaching test. Phase transformation during sintering was monitored using the powder XRD technique. The step-scanned XRD pattern of each powder sample was recorded by a Bruker D8 Advance X-ray powder diffractometer equipped with $\mathrm{Cu}$ $\mathrm{K} \alpha_{1,2} \mathrm{X}$-ray radiation source ( $40 \mathrm{kV}, 40 \mathrm{~mA}$ ) and a LynxEye detector. The $2 \theta$ scanning range was 10 to $90^{\circ}$, and the step size was $0.02^{\circ}$ with a scan speed of 0.8 s/step. Qualitative phase identification was executed by matching powder XRD patterns with 
those retrieved from the standard powder diffraction database of the International Centre for Diffraction Data (ICDD PDF-2, Release 2008).

\subsection{Leaching procedure}

A prolonged leaching test was employed in this study to further the discussion of the long-term leachability and leaching behavior of waste materials. As the goal of this test was to distinguish the leaching characteristics of different copper-bearing phases, single-phase samples were considered preferable in the leaching experiment. Therefore, after identifying the potential copper-containing phase(s) in the sintered products, single-phase copper samples were further fabricated by extending the sintering time. In the modified leaching procedure, $10 \mathrm{~mL}$ of $\mathrm{pH} 2.9$ acetic acid solution was used as the leaching fluid for $0.5 \mathrm{~g}$ of sample powder in each leaching vial. The leaching vials were rotated end-over-end at $60 \mathrm{rpm}$ for agitation periods of 0.75 to 22 days. At the end of each agitation period, the leachates were filtered with $0.2 \mu \mathrm{m}$ syringe filters. Their $\mathrm{pH}$ values were measured with a $\mathrm{pH}$ meter (Thermo Scientific), and their metal concentrations with an ICP-AES (Perkin-Elmer Optima 3300 DV).

\section{RESULTS AND DISCUSSION}

\subsection{Characterization of raw materials}

The XRD pattern of the $105{ }^{\circ} \mathrm{C}$ dried electroplating sludge in Figure 1 shows that the predominant crystalline Cu-containing phase was detected to be posnjakite $\left(\mathrm{Cu}_{4}\left(\mathrm{SO}_{4}\right)(\mathrm{OH})_{6}\left(\mathrm{H}_{2} \mathrm{O}\right)\right.$, PDF\#83-1410). Other Cu-containing crystalline phases were identified as malachite $\left(\mathrm{Cu}_{2}(\mathrm{OH})_{2} \mathrm{CO}_{3}, \mathrm{PDF} \# 76-0660\right)$ and copper oxide (CuO, PDF\#80-1268). The XRD pattern in Figure 2 further indicates that the aluminum component may exist as mullite and poor-crystalline phase(s) in the calcined sludge. A strong quartz signal was also found, which may reflect the second-largest component (silicon) detected by XRF. 


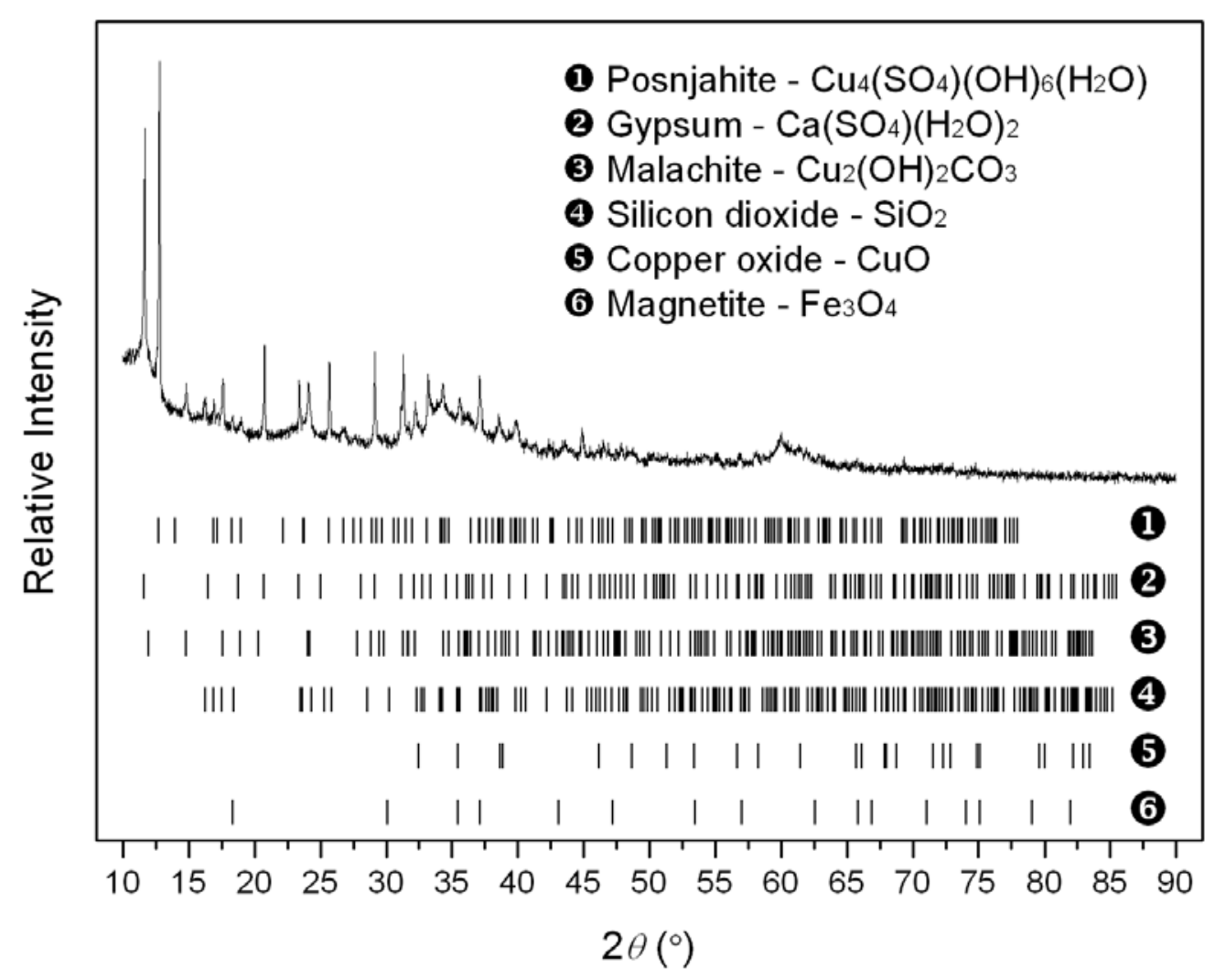

Figure 1. XRD pattern of the dehydrated copper-bearing electroplating sludge. The crystalline phases are identified as: (1 posnjakite $\left(\mathrm{Cu}_{4}\left(\mathrm{SO}_{4}\right)(\mathrm{OH})_{6}\left(\mathrm{H}_{2} \mathrm{O}\right)\right.$, PDF\#83-1410); 2 gypsum $\left(\mathrm{Ca}\left(\mathrm{SO}_{4}\right)\left(\mathrm{H}_{2} \mathrm{O}\right)_{2}, \quad \mathrm{PDF} \# 70-0982\right) ; \quad$ (3 malachite $\left(\mathrm{Cu}_{2}(\mathrm{OH})_{2} \mathrm{CO}_{3}\right.$, PDF\#76-0660); 4 silicon oxide $\left(\mathrm{SiO}_{2}, \mathrm{PDF} \# 82-1569\right)$; $\boldsymbol{\Theta}$ copper oxide (CuO, PDF\#80-1268); $\boldsymbol{\Theta}$ magnetite $\left(\mathrm{Fe}_{3} \mathrm{O}_{4}\right.$, $\left.\mathrm{PDF} 0866\right)$.

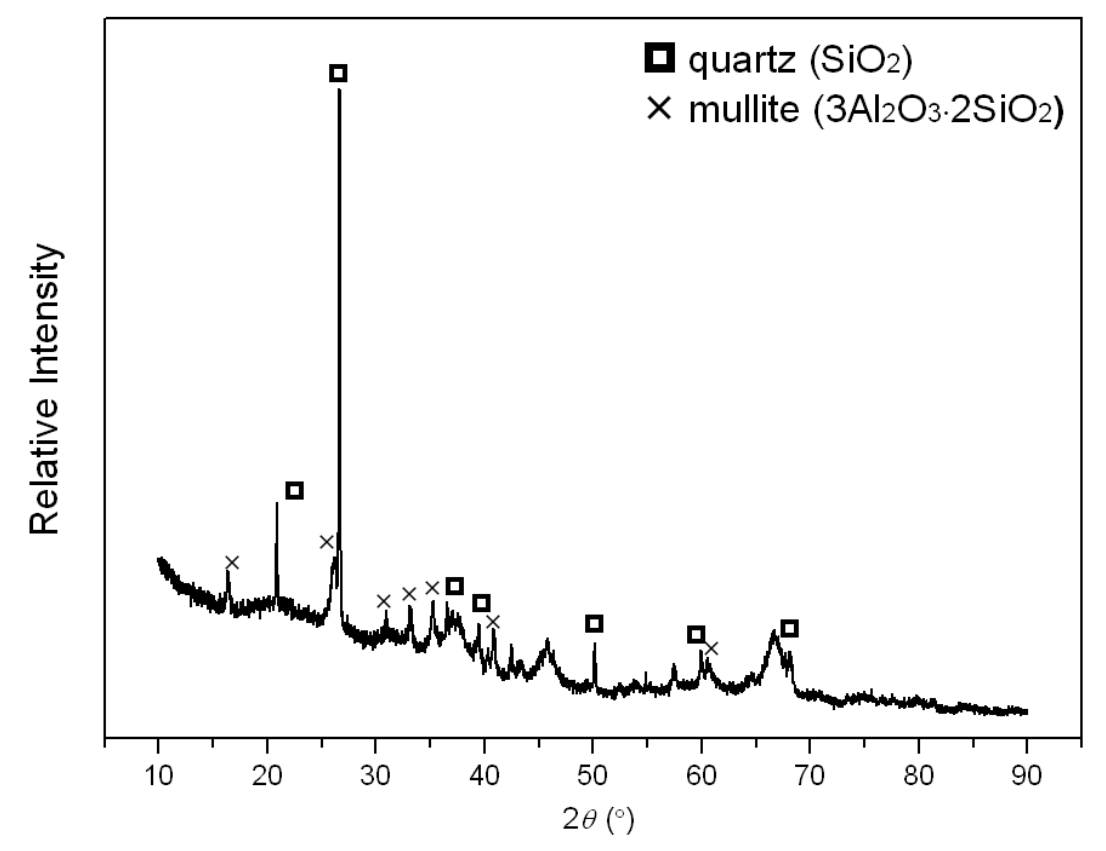

Figure 2. XRD pattern of waterworks sludge calcined at $900{ }^{\circ} \mathrm{C}$ for $30 \mathrm{~min}$. The standard patterns retrieved from the ICDD database include quartz $\left(\mathrm{SiO}_{2}\right.$, 
PDF\#79-1910) and mullite ( $\left.3 \mathrm{Al}_{2} \mathrm{O}_{3} \cdot 2 \mathrm{SiO}_{2}, \mathrm{PDF} 79-1455\right)$.

\subsection{Incorporation of copper during sintering process}

XRD patterns in Figure 3 demonstrate the phase transformation at temperatures ranging from 650 to $1150{ }^{\circ} \mathrm{C}$ in a 3-h sintering scheme. The peaks of $\mathrm{CuAl}_{2} \mathrm{O}_{4}$ phase were first observed in the $650{ }^{\circ} \mathrm{C}$ sintered sample. The increased peak intensity was found in the sample sintered at $850{ }^{\circ} \mathrm{C}$ for $3 \mathrm{~h}$. However, the substantial development of the $\mathrm{CuAl}_{2} \mathrm{O}_{4}$ spinel phase occurred when the sample was sintered at $1000{ }^{\circ} \mathrm{C}$. The signal of $\mathrm{CuAl}_{2} \mathrm{O}_{4}$ spinel phase continued until the temperature reached $1150{ }^{\circ} \mathrm{C}$. Further heating will cause the generation of the other copper-containing phases, i.e. $\mathrm{CuAlO}_{2}, \mathrm{Cu}_{2} \mathrm{O}$ and $\mathrm{CuO}$. The decomposition of $\mathrm{CuAl}_{2} \mathrm{O}_{4}$ spinel at higher temperatures can be organized in the following way (Tang et al., 2010):

$$
\begin{aligned}
& 2 \mathrm{CuAl}_{2} \mathrm{O}_{4} \rightarrow 2 \mathrm{CuAlO}_{2}+\mathrm{Al}_{2} \mathrm{O}_{3}+0.5 \mathrm{O}_{2} \\
& 2 \mathrm{CuO} \rightarrow \mathrm{Cu}_{2} \mathrm{O}+0.5 \mathrm{O}_{2} \\
& \mathrm{Cu}_{2} \mathrm{O}+\mathrm{Al}_{2} \mathrm{O}_{3} \rightarrow 2 \mathrm{CuAlO}_{2}
\end{aligned}
$$

When the transformation of aluminum and silicon was considered, at temperatures lower than the decomposition temperature of the $\mathrm{CuAl}_{2} \mathrm{O}_{4}$ spinel, the excess aluminum and silicon existed as mullite, together with the calcium silicate phase. But at higher temperatures, due to the decomposition of the $\mathrm{CuAl}_{2} \mathrm{O}_{4}$ spinel structure the excess aluminum existed as $\alpha-\mathrm{Al}_{2} \mathrm{O}_{3}$, which was different from the regeneration of mullite phase when sintering $\mathrm{CuO}$ with kaolinite and mullite precursors (Tang et al., 2011).

According to the $\mathrm{CuAl}_{2} \mathrm{O}_{4} \mathrm{XRD}$ pattern database (PDF\#78-1605), its major peaks are located at $2 \theta=36.868$, corresponding to the diffraction planes of (3 11 ). Therefore, the $2 \theta$ range of $36.5-37.2^{\circ}$ was selected to further observe the variation of $\mathrm{CuAl}_{2} \mathrm{O}_{4}$ spinel with the elevated temperatures (Figure 4). The substantial increase of $\mathrm{CuAl}_{2} \mathrm{O}_{4}$ peak intensity occurred at $950{ }^{\circ} \mathrm{C}$, and similar peak intensities within the temperature range of $950-1050{ }^{\circ} \mathrm{C}$ were observed. The decomposition of $\mathrm{CuAl}_{2} \mathrm{O}_{4}$ spinel was observed with the decrease of $\mathrm{CuAl}_{2} \mathrm{O}_{4}$ peak intensity due to the reaction shown in Eqs. (1-3). 


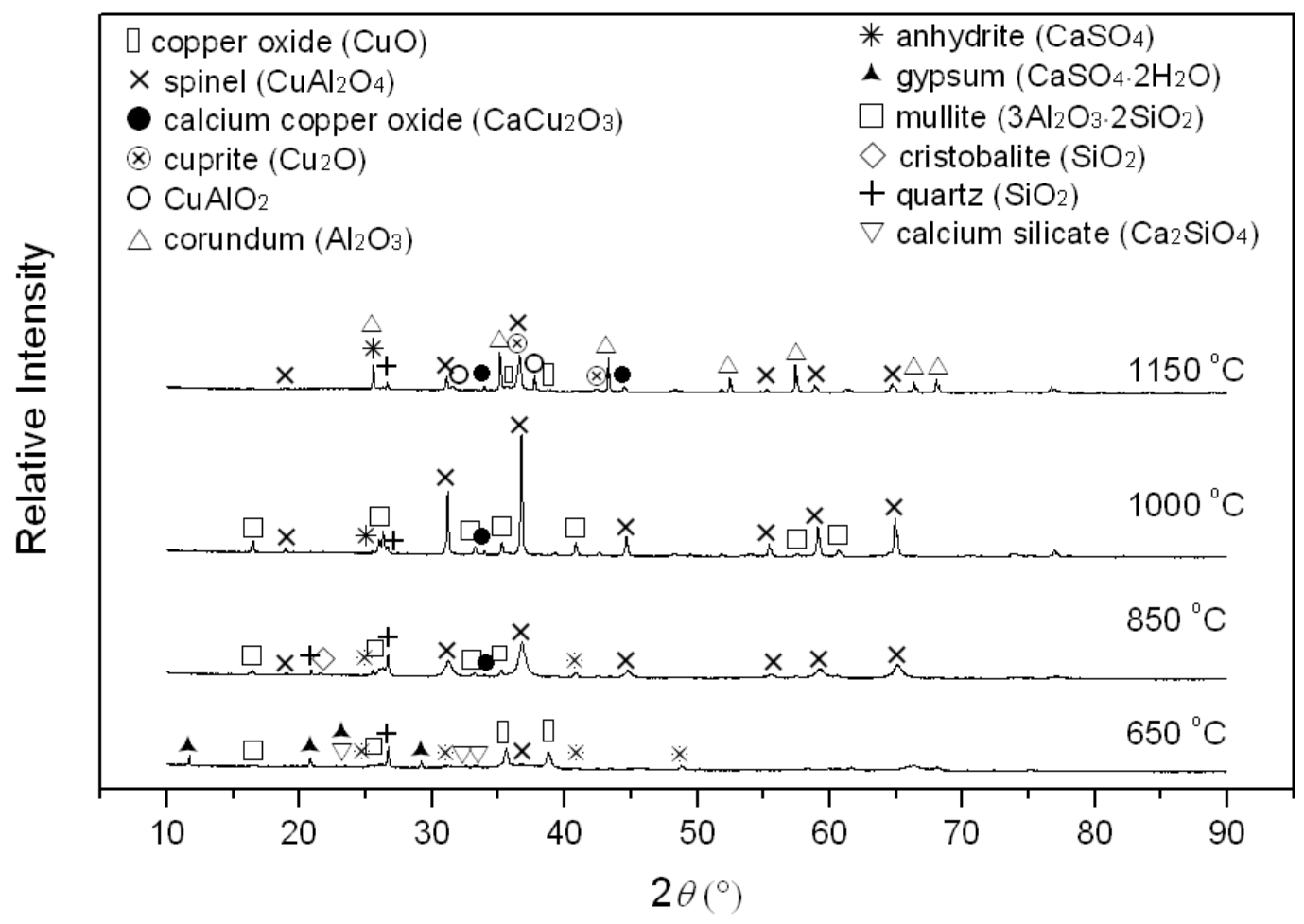

Figure 3. XRD patterns of the Cu-electroplating sludge + waterworks sludge system sintered at 650 to $1150{ }^{\circ} \mathrm{C}$ for $3 \mathrm{~h}$. The crystalline phases are identified as: $\mathrm{CuO}$ (PDF\#80-1268), $\mathrm{CuAl}_{2} \mathrm{O}_{4}$ (PDF\#78-1605), $\mathrm{CaCu}_{2} \mathrm{O}_{3}$ (PDF\#34-0284), $\mathrm{Cu}_{2} \mathrm{O}$ (PDF\#77-0199), $\quad \mathrm{CuAlO}_{2}$ (PDF\#75-2356), $\alpha-\mathrm{Al}_{2} \mathrm{O}_{3}$ (PDF\#10-0173), anhydrite ( $\left.\mathrm{CaSO}_{4}, \mathrm{PDF} \# 37-1496\right), \mathrm{CaSO}_{4} \cdot 2 \mathrm{H}_{2} \mathrm{O}$ (PDF\#70-0982) mullite (PDF\#79-1455), cristobalite (PDF\#76-0938), quartz (PDF\#79-1910), and calcium silicate $\left(\mathrm{CaSiO}_{4}\right.$, PDF\#33-0303). 


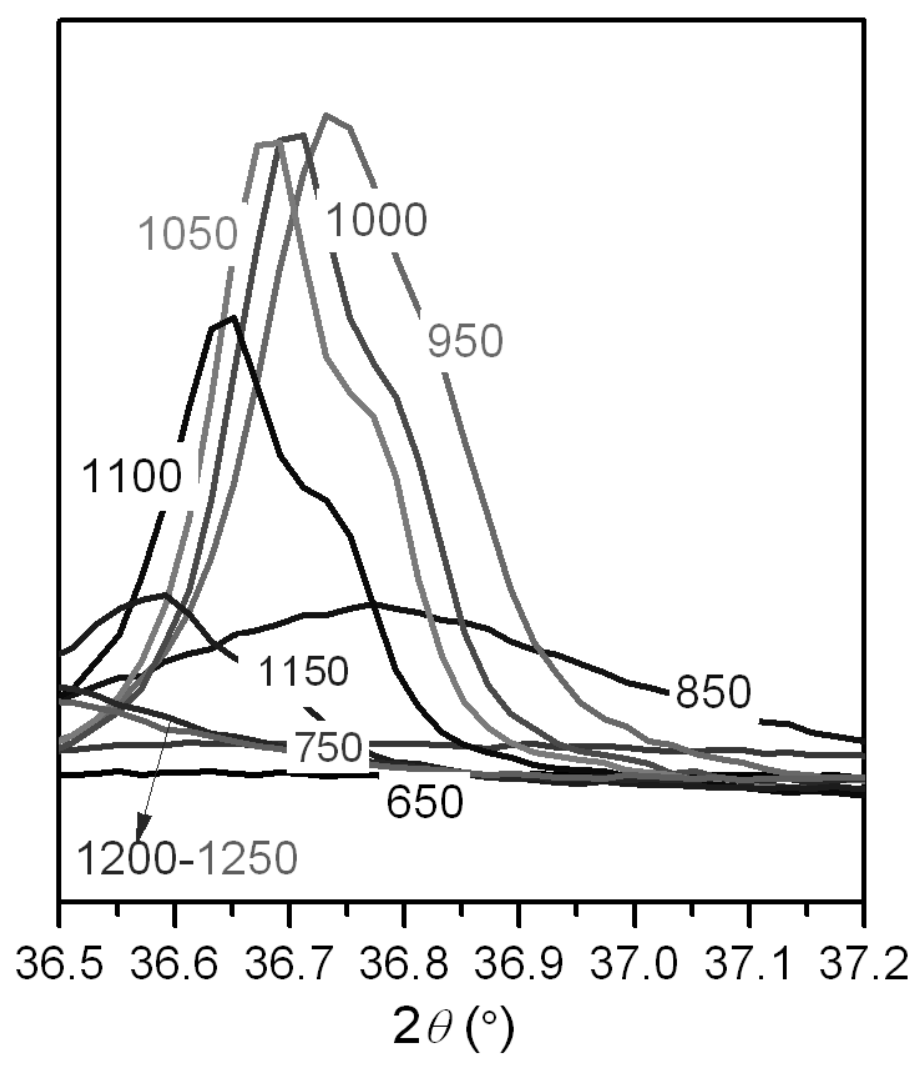

Figure 4. Comparison of the growth of $\mathrm{CuAl}_{2} \mathrm{O}_{4}$ spinel phase by XRD patterns in $2 \theta$ between $36.6^{\circ}$ and $37.2^{\circ}$ for the $\mathrm{Cu}$-electroplating sludge + waterworks sludge samples sintered at $650-1250{ }^{\circ} \mathrm{C}$ for $3 \mathrm{~h}$.

\subsection{Leachability of copper in product phase(s)}

From section 3.2, the $\mathrm{CuAl}_{2} \mathrm{O}_{4}$ spinel was the predominant copper-containing product phase when sintering copper-sludge with waterworks sludge. Therefore, single-phase $\mathrm{CuAl}_{2} \mathrm{O}_{4}$ was prepared for the prolonged leaching experiments. To ensure the complete transformation into the $\mathrm{CuAl}_{2} \mathrm{O}_{4}$ without residual reactants, the $\mathrm{Cu} / \mathrm{Al}$ molar ratio $=1: 2$ mixture pellets were sintered at $990{ }^{\circ} \mathrm{C}$ for $20 \mathrm{~d}$ and ball milled into powder form. The leachability of $\mathrm{CuO}$, as the mainly existed form in copper-laden sludge heating without any addictives, was compared with that of $\mathrm{CuAl}_{2} \mathrm{O}_{4}$ product phase. When leaching $\mathrm{CuO}$ and $\mathrm{CuAl}_{2} \mathrm{O}_{4}$ samples in an acidic environment, the reaction processes can be described as:

$$
\begin{aligned}
& \mathrm{CuO}+2 \mathrm{H}^{+} \rightarrow \mathrm{Cu}^{2+}+\mathrm{H}_{2} \mathrm{O} \\
& \mathrm{CuAl}_{2} \mathrm{O}_{4}+8 \mathrm{H}^{+} \rightarrow \mathrm{Cu}^{2+}+2 \mathrm{Al}^{3+}+4 \mathrm{H}_{2} \mathrm{O}
\end{aligned}
$$

The copper concentrations in both the $\mathrm{CuO}$ and $\mathrm{CuAl}_{2} \mathrm{O}_{4}$ leachates are presented in Figure 5. The leached copper in CuO leachate reached around $2000 \mathrm{mg} / \mathrm{L}$. However, throughout the entire leaching process, the concentration of the leached copper from the $\mathrm{CuAl}_{2} \mathrm{O}_{4}$ was significantly lower than that of the $\mathrm{CuO}$ leachate at the end of 
leaching experiment. Figure 5 and its inset show that the leached copper from the $\mathrm{CuO}$ sample is two orders of magnitude greater than that from the $\mathrm{CuAl}_{2} \mathrm{O}_{4}$ sample. The result of prolonged leaching test favorably confirmed the good stabilization achieved through incorporating copper into a $\mathrm{CuAl}_{2} \mathrm{O}_{4}$ structure.

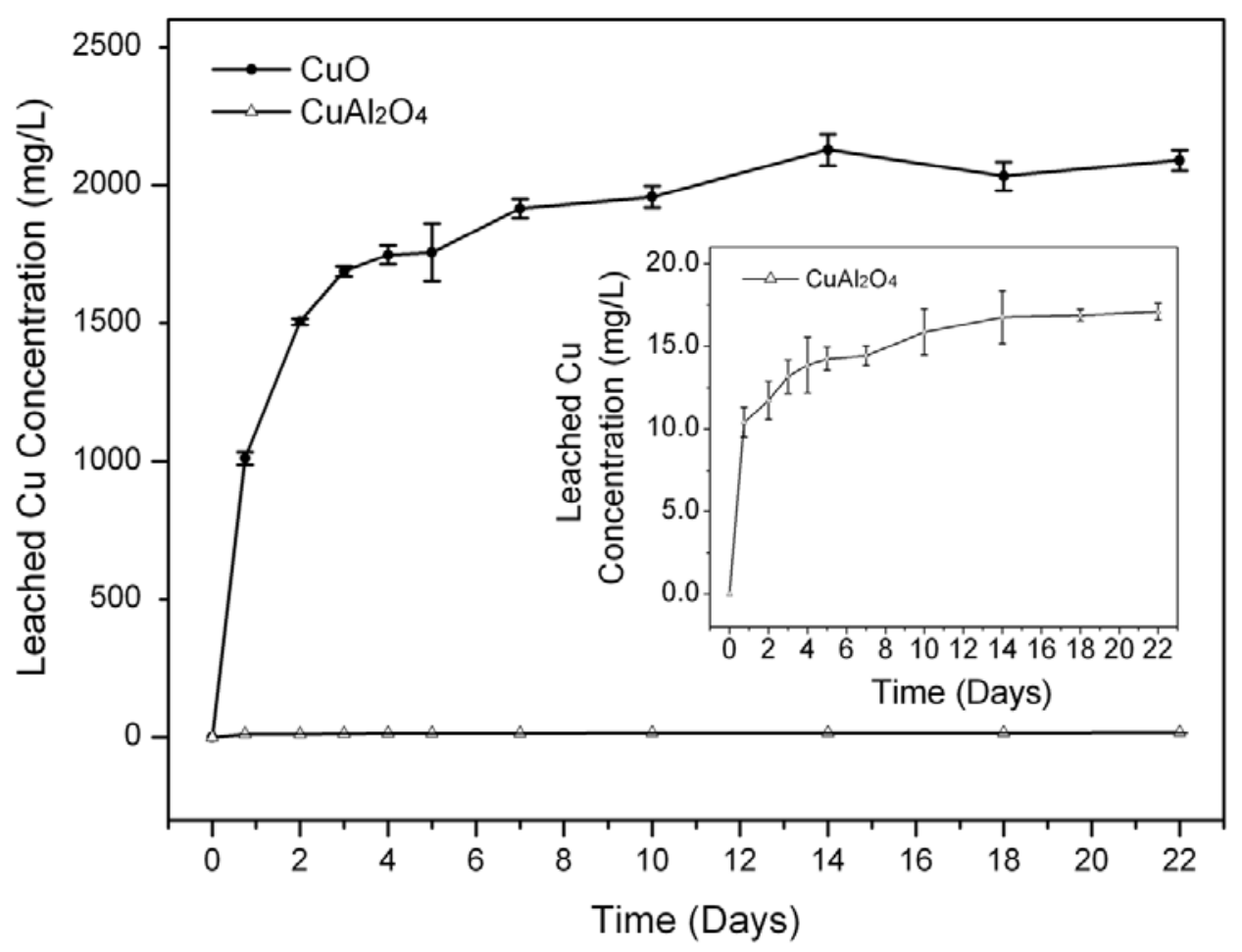

Figure 5. Variation of copper concentrations in the leachates from $\mathrm{CuO}$ and $\mathrm{CuAl}_{2} \mathrm{O}_{4}$ powder samples. The leaching solutions were acetic acid solution at $\mathrm{pH}$ 2.9. Each leaching vial was filled with $10 \mathrm{~mL}$ of extraction fluid and $0.5 \mathrm{~g}$ of powder, and then tumbled end-over-end from 0.75 to $22 \mathrm{~d}$.

\section{CONCLUSIONS}

When sintering the mixtures of copper-electroplating sludge and waterworks sludge precursors, the peaks of the $\mathrm{CuAl}_{2} \mathrm{O}_{4}$ phase were clearly identified, together with the disappearance of the initial copper-hosting phases (posnjakite, malachite) in the starting material. Sintering the sample mixture at $850{ }^{\circ} \mathrm{C}$ shows a distinguishable $\mathrm{CuAl}_{2} \mathrm{O}_{4}$ peak, and a substantial peak development was found at $950{ }^{\circ} \mathrm{C}$. The maximum generation of the $\mathrm{CuAl}_{2} \mathrm{O}_{4}$ spinel was observed at around $1000{ }^{\circ} \mathrm{C}$, and the $\mathrm{CuAlO}_{2}$ phase was observed at temperatures higher than $1100{ }^{\circ} \mathrm{C}$. The leaching results show explicitly that the $\mathrm{CuAl}_{2} \mathrm{O}_{4}$ product phase is superior to the copper oxide phase for immobilizing hazardous copper over longer leaching periods.

As the waterworks sludge is able to initiate the crystallization of the $\mathrm{CuAl}_{2} \mathrm{O}_{4}$ at an attainable sintering temperature $\left(\sim 1000{ }^{\circ} \mathrm{C}\right)$, the incorporation of copper-sludge into the fabrication process of some common ceramic products, such as those used for 
construction purposes, may be an effective and economical strategy to reduce the environmental hazard of copper-laden sludge.

\section{REFERENCES}

Babatunde A.O. \& Zhao Y.Q. (2007) Constructive approaches toward water treatment works sludge management: An international review of beneficial reuses. Crit. Rev. Env. Sci. Tec., 37, 129-164.

Chen Y.L., Ko M.S., Lai Y.C., Chang J.E. (2011) Hydration and leaching characteristics of cement pastes made from electroplating sludge. Waste Manage, 31, 1357-1363.

Malviya R., \& Chaudhary R. (2006) Factors affecting hazardous waste solidification/stabilization: A review. J. Hazard. Mater., 137, 267-276.

Peng G. \& Tian G. (2010) Using electrode electrolytes to enhance electrokinetic removal of heavy metals from electroplating sludge. Chem. Eng. J., 165, 388-394.

Sophia A.C. \& Swaminathan K. (2005) Assessment of the mechanical stability and chemical leachability of immobilized electroplating waste. Chemosphere, 58, 75-82.

Tang Y., Shih K., Chan K. (2010) Copper aluminate spinel in the stabilization and detoxification of simulated copper-laden sludge. Chemosphere, 80, 375-380.

Tang Y., Chui S.S.Y., Shih K., Zhang L. (2011) Copper stabilization via spinel formation during the sintering of simulated copper-laden sludge with aluminum-rich ceramic precursors. Environ. Sci. Technol., 45, 7609-7610.

Vicenzi J., Moura Bernardes A., Perez Bergmann C. (2005) Evaluation of alum sludge as raw material for ceramic products. J. Ind. Ceram., 25, 171-180

Wang Q. (2006) Industrial solid waste disposal and recycling, China Environmental Science Press, Beijing.

Yousuf M., Mollah A., Vempati R.K., Lin T.C., Cocke D.L. (1995) The Interfacial Chemistry of Solidification Stabilization of Metals in Cement and Pozzolanic Material Systems. Waste Manage, 15, 137-148.

Zhou Q., Milestone N.B., Hayes M. (2006) An alternative to Portland Cement for waste encapsulation-The calcium sulfoaluminate cement system. J. Hazard. Mater., 136, 120-129. 